\title{
PENINGKATAN PENGUASAAN MATERI PEMBELAJARAN DAUR AIR MELALUI PENDEKATAN SAINTIFIK BERMEDIA VIDEO NARASI BAGI PESERTA DIDIK TUNARUNGU
}

\author{
Titik Umi Nurhidajati \\ SLB-B YPLB Purwodadi Grobogan Jawa Tengah \\ Email: titik.mom07@gmail.com
}

\begin{abstract}
Abstrak
Penelitian ini membahas tentang bagaimana pendekatan saintifik bermedia video narasi diimplementasikan di SLB-YPLB Purwodadi dan menguji adanya peningkatan penguasaan materi pembelajaran daur air pada tema peristiwa dalam kehidupan bagi peserta didik tunarungu menggunakan pendekatan tersebut. Rancangan penelitian berupa penelitian tindakan kelas yang dilaksanakan dalam dua siklus. Hasil penelitian menunjukkan bahwa implementasi pendekatan saintifik bermedia video narasi berhasil meningkatkan penguasaan materi pembelajaran daur air tema peristiwa dalam kehidupan pada peserta didik tunarungu. Ketuntasan belajar klasikal pada siklus II mengalami peningkatan sebesar 25\% untuk penilaian pengetahuan dan 50\% untuk penilaian keterampilan.
\end{abstract}

Kata kunci: pembelajaran daur air, pendekatan saintifik, media video narasi.

\section{PENDAHULUAN}

Proses pembelajaran materi Daur Air pada tema Peristiwa dalam Kehidupan bagi peserta didik yang mengalami hambatan pendengaran (tunarungu) tentunya berbeda dengan peserta didik yang tidak memiliki hambatan pendengaran. Pertanyaan-pertanyaan mengenai "Dari mana datangnya air?", "Mengapa air tidak kunjung habis, walaupun kita gunakan setiap hari?", menjadi sesuatu yang sulit dipahami oleh peserta didik tunarungu.

Peserta didik tunarungu tidak memiliki perbendaharaan kata yang cukup untuk kepentingan akademis yang lebih tinggi, sehingga sebagai kenyataan kemampuan akademis peserta didik tunarungu berada di bawah rata-rata kemampuan anak normal. Sebagaimana yang dikemukakan oleh Moores (2001) bahwa, "hearing loss significantly influences the language and speech development of students who are deaf and hard-of-hearing that negatively affects their academic achievement, social and emotional interaction, and cognitive milestones." Sedangkan Somantri (2016) juga menyatakan bahwa perkembangan kognitif anak tunarungu sangat dipengaruhi oleh perkembangan bahasa, sehingga hambatan pada bahasa akan menghambat perkembangan intelegensi anak tunarungu.

Materi pembelajaran Daur Air termasuk dalam pelajaran IPA atau sering disebut sains. Sehubungan dengan adanya hambatan atau permasalahan pada perkembangan bahasa dan perkembangan kognitif peserta didik tunarungu, maka dalam mengajarkan sains bagi peserta didik tunarungu ditemui beberapa hambatan, seperti pada penelitian Jones (2014) yang menyatakan bahwa "current science teaching presents a range of difficulties for deaf students particularly when abstract concept are delivered using a didactic approach with a reliance on text books. Research also identifies that inferencing skills and language needed to articulate findings are often underdeveloped in deaf students. " Dari pernyataan tersebut dijelaskan bahwa mengajarkan sains bagi peserta didik tunarungu menyajikan berbagai kesulitan, yaitu terutama ketika konsep abstrak yang disampaikan dengan menggunakan pendekatan didaktis dengan ketergantungan pada buku teks. Penelitian juga menunjukkan bahwa keterampilan inferensia dan bahasa yang dibutuhkan untuk mengeluarkan pikiran kurang berkembang pada peserta didik tunarungu. 
Berdasarkan pengamatan dan pengalaman peneliti selama mengajar peserta didik tunarungu Kelas V di SLB-B YPLB Purwodadi, peserta didik tunarungu mengalami kesulitan menguasai materi pembelajaran tentang Daur Air. Hasil tes formatif di semester I tahun pelajaran 2018/2019 menunjukkan bahwa peserta didik yang berinisial AN mendapatkan nilai 70, ML mendapatkan nilai 65, IK mendapatkan nilai 55, AB mendapatkan nilai 50. Menurut hasil refleksi diri peneliti (Self-Reflective Inquiry), kondisi ini disebabkan oleh (1) faktor peserta didik, (2) faktor guru, (3) faktor metode atau pendekatan pembelajaran dan (4) faktor media pembelajaran yang digunakan. Faktor dari peserta didik meliputi kosa kata yang dimiliki peserta didik atau istilah ilmiah yang berhubungan dengan tema sangat terbatas, ada peserta didik yang belum mampu membaca, dan peserta didik sulit memahami konsep yang abstrak. Faktor guru meliputi mengajar secara monoton, tidak kreatif, dan tidak membuat perencanaan pembelajaran yang baik. Faktor metode pembelajaran, meliputi: hanya menggunakan metode ceramah, tanya jawab, dan penugasan, sehingga pembelajaran hanya berpusat pada guru, yang menyebabkan peserta didik menjadi kurang aktif, dan metode pembelajarannya masih berpusat pada guru, peserta didik sekedar memperhatikan dan terkadang menirukan dan menyalin saja, pembelajaran kurang menarik dan kurang divisualisasikan. Faktor media pembelajaran yang digunakan, meliputi; menggunakan media pembelajaran sekedarnya, sehingga pembelajaran tidak menarik.

Berangkat dari kondisi tersebut, peneliti sebagai guru Kelas V SLB berupaya meningkatkan kualitas pembelajaran, memperbaiki cara mengajar dengan menggunakan pendekatan pembelajaran yang tepat, dan menggunakan media yang sesuai dengan kebutuhan peserta didik tunarungu. Upaya yang dilakukan peneliti adalah menerapkan pendekatan saintifik dengan media video narasi. Pemilihan pendekatan saintifik juga didasarkan atas temuan empiris dari penelitian yang dilakukan oleh: (1) Machin (2014) yang menemukan bahwa penerapan pendekatan saintifik berpengaruh positif terhadap belajar kognitif, afektif, dan psikomotor, serta telah mencapai ketuntasan klasikal yang ditetapkan; (2) Prahastiwi, Subani \& Haryoto (2012) yang menunjukkan bahwa penerapan pendekatan saintifik sudah berjalan dengan baik dan dapat meningkatkan rasa ingin tahu peserta didik, serta dapat meningkatkan prestasi belajar peserta didik; (3) Rashidi, dkk (2015) menunjukkan bahwa bahan ajar dengan pendekatan saintifik penggunaannya efektif untuk meningkatkan keterampilan berpikir kritis peserta didik.

Media pembelajaran yang digunakan selama implementasi pendekatan saintifik ini disesuaikan dengan karakteristik dan kebutuhan peserta didik tunarungu. Karakteristik peserta didik yang mengalami hambatan pendengaran yaitu mengalihkan pengamatannya kepada mata untuk memperoleh informasi. Informasi yang diperoleh peserta didik tunarungu sebagian besar berupa informasi visual. Oleh karena itu pemilihan media pembelajaran video narasi dirasa tepat bagi peserta didik tunarungu sebab dengan media visual yang bergerak (video) yang disertai dengan penjelasan berupa tulisan (narasi) yang dibuat singkat namun tidak mengubah esensi materi pembelajarannya, akan membantu peserta didik mengkonkritkan materi pembelajaran yang abstrak. Pemilihan media tersebut didukung teori "Vision is the most important sense for deaf people as through this sense they interact with society. Thus, the use of visual resources (structural models, photos, games) and conducting experiments in classrooms or laboratories may assist them in the acquisition of knowledge through linking theory to practice" (Dias, Livia, dkk., 2014). Penggunaan media video dalam proses pembelajaran telah terbukti dapat meningkatkan pemahaman peserta didik terhadap materi pembelajaran yang diberikan. Hal ini dibuktikan dari hasil penelitian yang dilakukan oleh: (1) Febriana, Yunus dan Tarmansyah (2014) dengan hasil bahwa media video efektif untuk meningkatkan kemampuan mengenal bahaya HIV/AIDS bagi remaja tunarungu di SLB 1 Ganting Bukittinggi; (2) Cirtha (2012) pada peserta didik Kelas VI SLB-B Negeri Singaraja, hasil analisis menunjukkan ketuntasan klasikal 50\% pada siklus I, ketuntasan klasikal $100 \%$ pada siklus II dan tanggapan peserta didik terhadap penerapan model pembelajaran kontekstual berbantuan media CD interaktif dilengkapi bahasa 
isyarat dalam pembelajaran IPA pada kategori positif; (3) Zamfirov \& Saeva (2012) menunjukkan bahwa visualisasi dalam pembelajaran dikembangkan di kegiatan kelas pada pembelajaran Ilmu Pengetahuan Alam untuk peserta didik dengan kebutuhan khusus, sehingga semua peserta didik, bisa berpartisipasi dalam proses pembelajaran; (4) Cassetari, Kamble \& James (2015) dengan hasil penelitian yang menunjukkan bahwa "Video-feedback meningkatkan komunikasi dalam keluarga dengan anak yang memiliki hambatan pendengaran masa prelingual dan mendorong interaksi orangtua-anak lebih terhubung.

Rumusan masalah dalam penelitian ini adalah: (1) bagaimana implementasi pendekatan saintifik ber media video narasi untuk meningkatkan penguasaan materi pembelajaran daur air pada tema peristiwa dalam kehidupan bagi siswa tunarungu Kelas V SLB-B YPLB Purwodadi tahun pelajaran 2018/2019? (2) apakah ada peningkatan penguasaan materi pembelajaran daur air pada tema peristiwa dalam kehidupan melalui implementasi pendekatan saintifik bermedia video narasi bagi siswa tunarungu Kelas V SLB-B YPLB Purwodadi tahun pelajaran 2018/2019?

Tujuan yang ingin dicapai dalam penelitian ini adalah (1) memperoleh gambaran aktual implementasi pendekatan saintifik bermedia video narasi untuk meningkatkan penguasaan materi pembelajaran daur air pada tema peristiwa dalam kehidupan bagi peserta didik tunarungu Kelas V SLB-B YPLB Purwodadi tahun pelajaran 2018/2019; (2) menemukan peningkatan kemampuan penguasaan materi pembelajaran daur air pada tema peristiwa dalam kehidupan melalui implementasi pendekatan saintifik bermedia video narasi bagi peserta didik tunarungu Kelas V SLB-B YPLB Purwodadi tahun pelajaran 2018/2019.

\section{LANDASAN TEORI DAN HIPOTESIS TINDAKAN}

\section{Materi Pembelajaran Daur Air bagi Peserta Didik Tunarungu}

Materi daur air pada tema peristiwa dalam kehidupan terdapat pada mata pelajaran IPA Kelas V SDLB Tunarungu. Daur air merupakan sirkulasi atau perputaran air secara berulang dalam suatu pola tertentu, mulai dari bumi ke atmosfer dan kembali lagi ke bumi. Daur air ini terjadi melalui proses penguapan (evaporasi), jatuhnya titik-titik air ke permukaan bumi (presipitasi) dan pengembunan (kondensasi). Air yang digunakan dalam kehidupan sehari-hari berasal dari suatu proses yang cukup panjang yang disebut daur air. Daur air adalah perputaran air yang terjadi di alam secara teratur dan berulang. Air yang berasal dari sungai, danau, dan sumber air lainnya akan mengalir ke laut. Air yang berada di laut, sungai dan danau akan mengalami penguapan. Penguapan menyebabkan air berubah wujud menjadi uap air yang akan naik ke angkasa. Uap air ini kemudian berkumpul menjadi gumpalan awan. Gumpalan awan yang ada di angkasa akan mengalami pengembunan karena suhu udara yang rendah. Pengembunan ini membuat uap air berubah wujud menjadi kumpulan titik-titik air yang tampak sebagai awan hitam. Titik-titik air yang semakin banyak akan jatuh ke permukaan bumi, yang dikenal sebagai hujan. Sebagian air hujan akan meresap ke dalam tanah dan yang lainnya akan tetap di permukaan. Air yang meresap ke dalam tanah inilah yang akan menjadi sumber mata air sedangkan air yang tetap di permukaan, akan dialirkan ke sungai, danau, dan saluran air lainnya. Air permukaan inilah yang akan menguap lagi nantinya membentuk rentetan peristiwa hujan.

\section{Pendekatan Saintifik pada Pembelajaran Tema Peristiwa dalam Kehidupan}

Implementasi Kurikulum 2013 dalam pembelajaran dengan pendekatan saintifik adalah proses pembelajaran yang dirancang sedemikian rupa agar peserta didik secara aktif mengkonstruk konsep, hukum atau prinsip melalui tahapan-tahapan mengamati (untuk mengidentifikasi atau menemukan masalah), merumuskan masalah, mengajukan atau merumuskan hipotesis, mengumpulkan data dengan berbagai teknik, menganalisis data, menarik kesimpulan dan mengomunikasikan konsep, hukum atau prinsip yang ditemukan. 
Pendekatan saintifik merupakan pendekatan pembelajaran yang berorientasi atau berpusat pada peserta didik (student-centered approach). Di dalam pembelajaran dengan pendekatan saintifik, peserta didik mengkonstruksi pengetahuan bagi dirinya. Bagi peserta didik, pengetahuan yang dimilikinya bersifat dinamis, berkembang dari sederhana menuju kompleks, dari ruang lingkup dirinya dan di sekitarnya menuju ruang lingkup yang lebih luas, dan dari yang bersifat konkret menuju abstrak. Sebagai manusia yang sedang berkembang, peserta didik telah, sedang, dan/atau akan mengalami empat tahap perkembangan intelektual, yakni sensori motor, pra-operasional, operasional konkret, dan operasional formal (Kemendikbud, 2013).

\section{Media Video Narasi pada Pembelajaran Peserta Didik Tunarungu}

Arsyad (2011) menyatakan bahwa video merupakan gambar-gambar dalam frame, dimana frame demi frame diproyeksikan melalui lensa proyektor secara mekanis sehingga pada layar terlihat gambar hidup. Narasi adalah suatu bentuk wacana yang berusaha menggambarkan dengan sejelasjelasnya kepada pembaca suatu peristiwa yang telah terjadi (Keraf, 2010). Jadi yang dimaksud dengan video narasi adalah bentuk wacana yang berusaha menggambarkan dengan sejelasjelasnya kepada pembaca suatu peristiwa yang terintegrasi dalam video sehingga terlihat pada layar. Narasi yang dapat diterapkan ke dalam video dapat berupa suara (audio) atau tulisan (teks). Pada pembelajaran bagi anak tunarungu memerlukan media pembelajaran yang divisualisasikan. Media pembelajaran yang berupa video narasi akan membantu pemahaman anak tunarungu terhadap konsep-konsep yang abstrak .

Materi pembelajaran yang mempunyai tingkat kesukaran tinggi sukar dipahami oleh peserta didik, apalagi oleh peserta didik tunarungu yang memiliki keterbatasan kosa kata, tentu tidaklah mudah memahami konsep secara utuh. Video yang kaya akan informasi untuk diinformasikan dalam proses pembelajaran dapat sampai ke peserta didik secara langsung. Selain itu, video menambah dimensi baru dalam pembelajaran. Peserta didik tidak hanya melihat gambar dari bahan ajar cetak dan suara dari program audio, tetapi di dalam video, peserta didik bisa memperoleh keduanya, yaitu gambar bergerak beserta suara yang menyertainya. Meskipun suara tidak tertangkap maksimal bagi peserta didik tunarungu, namun dengan adanya gambar pada video akan sangat membantu dalam memahami materi pembelajaran.

\section{Kerangka Berpikir}

Pembelajaran daur air pada tema peristiwa dalam kehidupan termasuk materi yang sulit bagi peserta didik tunarungu. Hasil tes formatif pada semester I tahun pelajaran 2018/2019 menunjukkan bahwa $75 \%$ siswa belum tuntas belajar tentang materi daur air. Pembelajaran selama ini masih berpusat pada guru. Pemberian tindakan dengan mengimplementasikan pendekatan saintifik bermedia video narasi diharapkan meningkatkan kemampuan siswa dalam menguasai materi pembelajaran daur air pada KI 3 (Kompetensi Inti Pengetahuan) dan KI 4 (Kompetensi Inti Keterampilan). Penelitian ini menguji hipotesis apakah pembelajaran daur air pada tema peristiwa dalam kehidupan melalui pendekatan saintifik bermedia video narasi dapat meningkatkan kemampuan penguasaan peserta didik dalam materi pembelajaran daur air.

\section{METODE PENELITIAN}

Penelitian ini menggunakan desain penelitian tindakan kelas (PTK) model Kemmis \& Mc. Taggart (2000). Penelitian tindakan kelas ini dilakukan secara bersiklus. Penelitian dimulai dengan studi pendahuluan (preliminary study) dengan cara self-reflective inquiry atau penelitian melalui refleksi diri. Self-reflective inquiry atau penelitian melalui refleksi diri, merupakan ciri PTK yang paling esensial (Wahyudi \& Sujarwanto, 2015). Pada penelitian melalui refleksi diri ini, peneliti mencoba mengingat kembali dan merenungkan apa yang sudah dilakukan dalam mengajarkan Materi Daur Air selama ini. Dari refleksi diri ditemukan kekuatan dan kelemahan dari tindakan 
guru selama ini, sehingga guru berusaha memperbaiki kelemahan dan mempertahankan kekuatan yang sudah dilakukan dalam pembelajaran. Selain refleksi diri, berdasarkan kenyataan bahwa dari dokumentasi hasil tes formatif untuk materi Daur Air pada tahun pelajaran 2018/2019 masih rendah, peneliti selanjutnya mengkaji literatur, mengkaji tindakan apa yang dapat dilakukan sesuai dengan permasalahan, dan konsultasi dengan ahli dalam proses pembelajaran. Setelah penelitian melalui refleksi diri, maka dilakukan penerapan langkah-langkah dalam siklus terdiri dari empat fase yaitu perencanaan (planning), pelaksanaan (action), pengamatan (observing) serta refleksi (reflecting).

Penelitian ini dilaksanakan di SLB-B YPLB Purwodadi. Subjek dari penelitian ini adalah peserta didik tunarungu jenjang SDLB di Kelas V yang berjumlah empat orang terdiri dari tiga lakilaki dan satu perempuan. Pemilihan subjek penelitian ini karena jenjang SDLB merupakan awal diberikannya pendidikan pengetahuan tentang alam terutama mengenai pengetahuan tentang air yang harus diberikan sedini mungkin sehingga masalah yang menjadi fokus pada penelitian ini dapat diatasi sedini mungkin.

Teknik pengumpulan data dilakukan dengan dokumentasi, observasi dan tes. Dokumentasi digunakan untuk memperoleh data tentang kemampuan awal yang diambil dari hasil nilai ulangan formatif peserta didik. Observasi dilakukan untuk mengamati aktivitas peserta didik dan aktivitas peneliti saat proses pembelajaran dan melihat kualitas pembelajaran yang dilakukan, dibantu oleh observer. Tes dilakukan untuk mengetahui hasil ketercapaian setiap kompetensi. Kompetensi yang dibuat untuk tes adalah kompetensi pengetahuan dan kompetensi keterampilan. Indikator keberhasilan tindakan pada penelitian tindakan ini adalah apabila $75 \%$ peserta didik tunarungu untuk penilaian pengetahuan dan penilaian keterampilan memperoleh $\mathrm{N} \geq 70$. Apabila target ini belum tercapai maka siklus akan dilanjutkan ke siklus-siklus berikutnya sampai target keberhasilan tercapai. Teknik analisis data dalam penelitian tindakan kelas ini menggunakan analisis data deskriptif kualitatif dan kuantitatif.

\section{HASIL DAN PEMBAHASAN}

Penelitian ini difokuskan pada peningkatan KI 3 (Kompetensi Inti Pengetahuan) dan KI 4 (Kompetensi Inti Keterampilan), namun demikian dalam kegiatan pembelajaran mencakup KI-1 (Kompetensi Sikap Spiritual) dan KI 2 (Kompetensi Sikap Sosial). Pembelajaran tentang proses Daur Air yang dilakukan melalui pendekatan saintifik dengan media video narasi ini, secara keseluruhan dilaksanakan 2 (dua) putaran siklus penelitian. Setiap putaran siklus terdiri dari 3 (tiga) kali pertemuan dengan alokasi waktu pertemuan masing-masing 2 x 35 menit.

\section{Deskripsi Hasil Penelitian Siklus I}

Pada siklus pertama, perencanaan dilakukan dengan (1) menyusun Rencana Pelaksanaan Pembelajaran (RPP). RPP dengan Tema Peristiwa dalam Kehidupan, Subtema Macam-macam Peristiwa dalam Kehidupan, pada Materi Daur Air ini, menerapkan pendekatan saintifik, (2) menyiapkan video dengan narasi yang disesuaikan dengan materi yang akan diajarkan, kemudian menyusun alat evaluasi untuk paket pertemuan pertama, kedua, dan ketiga pada Siklus I yaitu penilaian pengetahuan berupa soal pilihan ganda sebanyak 20 soal beserta kunci jawabannya, format penilaian keterampilan (instrumen penilaian unjuk kerja), format penilaian sikap spiritual, dan format penilaian sosial, (3) menyiapkan lembar observasi aktivitas guru, lembar observasi aktivitas peserta didik, lembar observasi sikap spiritual peserta didik, dan lembar observasi sikap sosial peserta didik pada masing-masing pertemuan.

Pelaksanaan pembelajaran siklus I dilakukan dalam tiga kali pertemuan. Pada pertemuan pertama disampaikan materi tentang dari mana saja kita dapat menemukan air, macam-macam kegunaan air, dan mengapa air penting bagi kita. Materi disampaikan melalui penayangan video narasi. 
Sesuai langkah-langkah pendekatan saintifik, pertama peserta didik tunarungu mengamati video yang ditayangkan, kemudian menanya dari apa yang peserta didik tunarungu belum pahami, mencari informasi (mencoba), berdiskusi (menalar) dan selanjutnya mengkomunikasikan hasil diskusi kelompok. Pada pertemuan kedua disampaikan materi tentang proses daur air. Materi disampaikan juga melalui penayangan video narasi, seperti pada pertemuan pertama. Langkahlangkah pendekatan saintifik juga diterapkan di pertemuan kedua ini, pertama peserta didik tunarungu mengamati video narasi tentang proses daur air, kemudian peserta didik tunarungu menanya yang belum dipahami, mencoba dan menalar, selanjutnya mengkomunikasikannya. Pada pertemuan ketiga disampaikan materi tentang kegiatan manusia yang mempengaruhi daur air dan tindakan menghemat air. Masih seperti pada pertemuan kedua, materi disampaikan juga melalui penayangan video narasi yang proses pembelajarannya menggunakan langkahlangkah pendekatan saintifik, pertama peserta didik tunarungu mengamati video narasi tentang kegiatan manusia yang mempengaruhi daur air dan contoh-contoh tindakan menghemat air bersih, kemudian peserta didik tunarungu menanya yang belum dipahami, mencoba dan menalar, selanjutnya mengkomunikasikannya.

Evaluasi dilakukan selama kegiatan pembelajaran berlangsung. Peneliti melakukan penilaian sikap spiritual, sikap sosial, pengetahuan dan keterampilan peserta didik tunarungu. Penilaian sikap spiritual, sosial dan keterampilan dinilai selama pembelajaran berlangsung dari pertemuan pertama sampai ketiga, sedangkan penilaian pengetahuan dilaksanakan setelah pertemuan ketiga berakhir berupa tes pengetahuan secara tertulis dengan soal pilihan ganda sebanyak 20 soal.

Hasil yang didapat pada siklus I menunjukkan bahwa untuk penilaian pengetahuan, sebanyak 2 peserta didik tunarungu (50\%) yang tuntas belajar, sedangkan 2 peserta didik tunarungu $(50 \%)$ belum tuntas belajar. Hasil penilaian pengetahuan tersebut belum memenuhi indikator keberhasilan tindakan yang ditentukan dalam penelitian yaitu tindakan dikatakan berhasil jika $75 \%$ peserta didik tunarungu telah mencapai $\mathrm{N} \geq 70$, sehingga pembelajaran masih perlu dilanjutkan ke tahap berikutnya yaitu siklus II. Untuk penilaian keterampilan, sebanyak 2 peserta didik tunarungu $(50 \%)$ yang tuntas belajar, sedangkan 2 peserta didik tunarungu $(50 \%)$ belum tuntas belajar. Hasil penilaian kompetensi keterampilan tersebut juga belum memenuhi indikator keberhasilan tindakan yang ditentukan dalam penelitian dikatakan berhasil jika 75\% peserta didik tunarungu telah mencapai Nilai $\geq 70$, sehingga pembelajaran masih perlu dilanjutkan ke tahap berikutnya yaitu siklus II.

Refleksi untuk siklus I yaitu: (1) Kegiatan guru dalam membimbing peserta didik tunarungu pada langkah pendekatan saintifik yang pertama, mengamati mengalami kendala, sebab peserta didik kesulitan menangkap beberapa kata atau istilah asing yang terdapat pada teks narasi di video yang sedang ditayangkan. Selain itu disebabkan karena penayangan video yang tidak diberi jeda sehingga terlalu cepat bagi peserta didik tunarungu untuk mengingat dan memahami, (2) Langkah menanya juga mengalami kendala sebab peserta didik tunarungu ragu-ragu dan tidak percaya diri dalam mengajukan pertanyaan. Kesulitan peserta didik tunarungu dalam bertanya merupakan akibat pemahaman peserta didik tunarungu pada tahap mengamati masih mengalami beberapa kendala. Akibat peserta didik tunarungu tidak cukup memahami makna kata atau istilah dalam teks (narasi) pada video yang ditayangkan, peserta didik tunarungu menjadi tidak percaya diri dan masih ragu-ragu untuk bertanya. (3) Langkah mencari informasi (mencoba) mengalami kendala yang masih berkaitan dengan kesulitan peserta didik tunarungu dalam memahami istilah asing atau beberapa kosa kata yang belum dimengerti yang ada pada teks (narasi) di video yang ditayangkan, sehingga peserta didik tunarungu kesulitan dalam mengidentifikasi tentang kegunaan air, proses daur air, dan bagaimana menghemat air, secara tepat. Peserta didik tunarungu seringkali lupa dengan tulisan yang ada pada teks (narasi) di video dan lupa atau ketinggalan mencatat kata-kata penting. (4) Kegiatan diskusi kelompok (menalar) mengalami kendala yaitu kurangnya kerjasama dalam kelompok. Peserta didik tunarungu masih bekerja sendiri-sendiri 
dan masih takut dalam menyampaikan pendapat. (5) Langkah mengkomunikasikan mengalami kendala yaitu peserta didik tunarungu masih kurang serius ketika disuruh maju di depan kelas menyampaikan hasil diskusi kelompoknya, peserta didik masih sambil bercanda dengan temannya saat menyampaikan hasil diskusi. Peserta didik tunarungu juga lupa urutan tahapan proses daur air, dan hasil membuat bagan daur air, masih ada keterangan tahapnya yang belum tepat.

\section{Deskripsi Hasil Penelitian Siklus II}

Pada siklus II dilakukan upaya perbaikan berdasarkan hasil refleksi dari pembelajaran pada siklus I. Perencanaan ulang ditekankan persiapan pemutaran video yang diperbaiki pada teknik penayangannya yaitu dengan pemberian jeda atau diberi pengulangan.

Pada saat pelaksanaan pembelajaran, peneliti melakukan perbaikan; (1) langkah mengamati, peneliti menayangkan video tidak terlalu cepat, diberi jeda di setiap kalimat pendek atau di setiap ada kata/istilah asing yang sulit dipahami oleh peserta didik tunarungu, kemudian dicarikan padanan kata yang lebih mudah dipahami, serta dibantu dengan bahasa isyarat, (2) langkah menanya, peneliti memberi motivasi secara personal dan terbuka sehingga peserta didik tunarungu tidak merasa takut atau enggan bertanya. Selanjutnya apabila peserta didik tunarungu masih raguragu bertanya, peserta didik diperbolehkan berkata-kata menurut apa yang ingin dia sampaikan. Kadang-kadang peserta didik berkata satu kata yang maksudnya ingin bertanya, tetapi karena masih bingung dengan susunan kalimat tanya, peserta didik hanya mengatakan satu atau dua kata saja. Pada saat inilah guru berperan memberi pertanyaan pancingan, sehingga guru memperjelas apa yang dimaksud oleh peserta didik tunarungu, sehingga menjadi kalimat pertanyaan atau ungkapan yang lebih baik dan jelas. Apabila peserta didik tidak mengerti kosa kata atau istilah yang belum dipahami, guru dapat menggunakan bahasa isyarat untuk mendukung kata atau istilah yang dikatakan/diucapkan, serta menuliskannya di papan tulis, (3) langkah mencari informasi (mencoba), peneliti memberi waktu yang cukup bagi peserta didik tunarungu untuk mencatat kata-kata penting yang ada pada video narasi saat ditayangkan, sehingga peserta didik masih berkesempatan mencatatnya dengan seksama, (4) kegiatan diskusi kelompok (menalar), peneliti memberikan pengertian pentingnya bekerja sama antar anggota kelompok dalam menyelesaikan suatu permasalahan dari apa yang ia pelajari. Peneliti memotivasi dan membimbing peserta didik tunarungu agar lebih aktif terlibat dalam diskusi, serta tidak perlu takut dalam menyampaikan pendapat dalam diskusi kelompok, (5) langkah mengkomunikasikan, peneliti mengarahkan peserta didik tunarungu agar lebih fokus dalam menyampaikan hasil diskusi dan memperbaiki gambar/bagan serta urutan tahapan proses daur air yang benar.

Evaluasi yang dilakukan pada siklus II sama dengan siklus I. Peneliti melakukan penilaian sikap spiritual, sikap sosial, pengetahuan dan keterampilan peserta didik tunarungu. Penilaian sikap spiritual, sosial dan keterampilan dinilai selama pembelajaran berlangsung dari pertemuan pertama sampai ketiga, sedangkan penilaian pengetahuan dilaksanakan setelah pertemuan ketiga berakhir berupa tes pengetahuan secara tertulis dengan soal pilihan ganda sebanyak 20 soal.

Hasil yang didapat pada siklus II menunjukkan bahwa untuk penilaian pengetahuan, sebanyak 3 peserta didik tunarungu (75\%) yang tuntas belajar, sedangkan 1 peserta didik tunarungu $(25 \%)$ belum tuntas belajar. Hasil penilaian pengetahuan tersebut sudah memenuhi indikator keberhasilan tindakan yang ditentukan dalam penelitian yaitu tindakan dikatakan berhasil jika $75 \%$ peserta didik tunarungu telah mencapai $\mathrm{N} \geq 70$, Berdasarkan hasil tersebut, maka ketuntasan belajar untuk penilaian pengetahuan peserta didik tunarungu pada siklus II telah tercapai dan sudah memenuhi target indikator keberhasilan tindakan yang telah ditetapkan. Untuk penilaian keterampilan, sebanyak 4 peserta didik tunarungu (100\%) yang tuntas belajar. Hasil penilaian kompetensi keterampilan tersebut sudah memenuhi indikator keberhasilan tindakan yang ditentukan dalam penelitian ini. Ketuntasan belajar pada kompetensi penilaian keterampilan 
pada siklus II telah tercapai dan melampaui target indikator keberhasilan tindakan yang telah ditetapkan sebesar $75 \%$.

Refleksi Siklus II yaitu hasil penilaian pengetahuan peserta didik tunarungu pada siklus II telah mencapai ketuntasan belajar klasikal sebesar 75\% dan hasil penilaian kompetensi keterampilan peserta didik tunarungu pada siklus II telah mencapai ketuntasan belajar klasikal sebesar 100\%. Berdasarkan hasil tersebut maka kesimpulan yang diperoleh adalah penelitian tindakan kelas ini cukup dilaksanakan sampai pada siklus II karena ketuntasan belajar peserta didik tunarungu pada penilaian pengetahuan dan penilaian keterampilan telah mencapai target indikator keberhasilan tindakan.

Peningkatan penguasaan materi pembelajaran Daur Air, dapat dilihat melalui hasil penilaian pengetahuan dan penilaian keterampilan pada tabel berikut ini.

Tabel Data Hasil Penilaian Pengetahuan dan Penilaian Keterampilan pada Siklus I dan Siklus II

\begin{tabular}{lcccc}
\hline \multirow{2}{*}{ Peserta Didik } & \multicolumn{2}{c}{ Hasil Penilaian Pengetahuan } & \multicolumn{2}{c}{ Hasil Penilaian Keterampilan } \\
\cline { 2 - 5 } & Siklus I & Siklus II & Siklus I & Siklus II \\
\hline AB & 60 & 65 & 65 & 75 \\
\hline AN & 90 & 100 & 75 & 90 \\
\hline IK & 65 & 75 & 65 & 75 \\
\hline ML & 80 & 85 & 70 & 30 \\
\hline Jumlah & 295 & 325 & 275 & 82,5 \\
\hline Rata-rata Kelas & 73,75 & 81,25 & 68,75 & $100 \%$ \\
\hline Persentase & $50 \%$ & $75 \%$ & $50 \%$ & \\
\hline
\end{tabular}

Dari hasil yang didapat, pembelajaran dengan menerapkan pendekatan saintifik bermedia video narasi dapat meningkatkan penguasaan materi pembelajaran tentang daur air pada tema peristiwa dalam kehidupan bagi peserta didik tunarungu. Peserta didik tunarungu menjadi lebih aktif dengan diimplementasikannya pendekatan saintifik berbantuan video narasi sebagai media pembelajaran pada materi daur air. Proses pembelajaran yang berpusat kepada peserta didik dan langkahlangkah pembelajarannya yang sistematis mengajak peserta didik tunarungu dan guru lebih aktif dan kreatif. Media yang digunakan juga mampu menarik antusias peserta didik tunarungu untuk mengikuti seluruh proses pembelajaran.

\section{Pembahasan}

Berdasarkan hasil observasi, sebagian besar peserta didik tunarungu pada dasarnya mampu mengikuti tahapan pada langkah-langkah pendekatan saintifik, dari mengamati, menanya, mencoba, menalar dan mengkomunikasikan, dengan pendampingan khusus dari guru. Pendampingan khusus yang dimaksud di sini adalah bahwa selama pelaksanaan langkah-langkah pendekatan saintifik di kelas peserta didik tunarungu tentunya berbeda dengan di kelas peserta didik yang tidak memiliki hambatan pendengaran. Di kelas peserta didik tunarungu, materi pembelajaran lebih disederhanakan, kegiatan seperti mengamati, menanya, mencoba, menalar, dan mengkomunikasikan, harus dibimbing/didampingi dalam pelaksanaannya. Hal ini disebabkan peserta didik tunarungu memiliki hambatan dalam memahami konsep ilmiah, seperti dinyatakan pada hasil penelitian Akram, dkk. (2013) yang menunjukkan bahwa "hearing students are more proficient in scientific concept as compared to their deaf counterparts." Artinya peserta didik yang tidak memiliki hambatan pendengaran lebih cakap dalam memahami konsep ilmiah jika dibandingkan dengan peserta didik yang mengalami hambatan pendengaran.

Temuan berikutnya yaitu ketika langkah pendekatan saintifik yang pertama mengamati, peserta didik tunarungu kesulitan menangkap beberapa kata-kata sulit atau istilah asing yang terdapat pada teks narasi di video yang ditayangkan. Setelah dilakukan upaya oleh guru dengan 
menayangkan video tidak terlalu cepat, diberi jeda pada setiap kalimat pendek atau di setiap ada kata/istilah asing yang sulit dipahami oleh peserta didik tunarungu, kemudian dicarikan padanan kata yang lebih mudah dipahami, serta dibantu dengan bahasa isyarat, peserta didik dapat memahami materi tersebut. Dalam mengajarkan konsep ilmiah bagi peserta didik tunarungu memang menyajikan berbagai kesulitan, salah satunya adalah mengenai kosa kata atau istilah asing yang sulit dipahami oleh peserta didik tunarungu, sehingga membuatnya menjadi sebuah pengertian yang abstrak bagi peserta didik tunarungu. Temuan ini sesuai dengan hasil penelitian Jones (2014) yang menunjukkan bahwa "current science teaching presents a range of difficulties for deaf students particularly when abstract concept are delivered using a didactic approach with a reliance on text books. Research also identifies that inferencing skills and language needed to articulate findings are often underdeveloped in deaf students".

Temuan selanjutnya yaitu peserta didik tunarungu kesulitan bertanya pada saat langkah pendekatan saintifik menanya, peserta didik tunarungu ragu-ragu dan tidak percaya diri dalam mengajukan pertanyaan. Temuan tersebut sesuai dengan teori tentang karakteristik peserta didik tunarungu berikut, “... karakteristik anak tunarungu menampakkan kebimbangan dan keraguraguan. Kesempatan untuk melihat kejadian, ketidakmampuannya untuk memahami kejadian secara menyeluruh menyebabkan perasaan curiga terhadap lingkungan dan kurang percaya diri" (Soemantri, 2006). Dalam penelitian ini, kesulitan peserta didik tunarungu dalam bertanya merupakan akibat pemahaman peserta didik tunarungu pada langkah mengamati terdapat kendala, yakni peserta didik tunarungu tidak cukup memahami makna kata atau istilah dalam teks (narasi) pada video yang ditayangkan, sehingga peserta didik tunarungu menjadi tidak percaya diri dan masih ragu-ragu untuk bertanya.

Temuan berikutnya yaitu pada langkah saintifik mencoba, peserta didik tunarungu seringkali lupa dengan tulisan yang ada pada teks (narasi) di video dan lupa atau ketinggalan mencatat kata-kata penting, sehingga lupa pula bacaannya. Temuan ini sesuai dengan hasil penelitian Traxler (2000) yang menunjukkan bahwa "Many students who are deaf or hard of hearing have significant problems in reading and writing area. These challenges impact student's ability to master content subject material, learn independently, and use technology." Artinya, beberapa peserta didik dengan hambatan pendengaran memiliki masalah yang signifikan dalam membaca dan menulis. Tantangan ini berdampak pada kemampuan peserta didik untuk menguasai materi pembelajaran, belajar secara mandiri, dan menggunakan teknologi. Upaya perbaikan telah dilakukan guru dalam implementasi pendekatan saintifik pada langkah mencoba ini, dengan memberi waktu yang cukup bagi peserta didik tunarungu untuk mencatat kata-kata penting yang ada pada video narasi saat ditayangkan, sehingga peserta didik masih berkesempatan mencatatnya dengan seksama.

Temuan selanjutnya pada kegiatan diskusi kelompok (langkah pendekatan saintifik menalar) dan mengkomunikasikan, peserta didik tunarungu bekerja secara sendiri-sendiri, takut menyampaikan pendapat, dan kurang serius dalam menyampaikan hasil diskusi. Beberapa temuan yang merupakan kesulitan atau kendala yang dialami peserta didik tunarungu di atas masih berkaitan dengan kurangnya vocabulary atau kosa kata yang dimiliki peserta didik tunarungu, sehingga untuk menyampaikan pendapat dalam diskusi, peserta didik tunarungu menjadi takut dan ragu-ragu untuk mengatakannya. Biemiller (2005) menyatakan bahwa "vocabulary development is strongly related to academic achievement because content subject instruction includes a large number of new and technical words and concepts. As a result, most students who are deaf or hard of hearing need supplementary instruction in language, vocabulary, and literacy. They are likely to have difficulty with the vocabulary and concept demands of many content-area discussion, lessons, and material presented in textbooks". Artinya, berkembangnya kosa kata sangat erat hubungannya dengan prestasi belajar karena muatan pelajaran banyak berisi kosa kata atau istilah teknis dan konsep yang baru. Akibatnya, peserta didik tunarungu memerlukan tambahan pembelajaran bahasa, kosa kata dan literasi. Mereka cenderung memiliki kesulitan 
dengan kosa kata dan tuntutan konsep untuk bidang diskusi, pelajaran, dan materi yang disajikan dalam teks buku.

Berdasarkan hasil penelitian dari siklus I dan siklus II menunjukkan terjadinya peningkatan penguasaan materi pembelajaran daur air pada tema peristiwa dalam kehidupan yang dilihat dari hasil penilaian pengetahuan dan hasil penilaian keterampilan. Pada siklus I berdasarkan analisis data hasil penilaian pengetahuan seluruh peserta didik diketahui bahwa sebanyak 2 peserta didik (50\%) yang tuntas belajar, sedangkan 2 peserta didik $(50 \%)$ belum tuntas belajar. Berdasarkan analisis data penilaian keterampilan seluruh peserta didik diketahui bahwa sebanyak 2 peserta didik (50\%) yang tuntas, sedangkan 2 peserta didik (50\%) belum tuntas. Hasil penilaian pengetahuan dan penilaian keterampilan belum memenuhi indikator keberhasilan tindakan yang ditentukan dalam penelitian ini yaitu penelitian dikatakan berhasil jika $75 \%$ peserta didik telah mencapai $\mathrm{N} \geq 70$. Berdasarkan analisis tersebut maka pembelajaran masih perlu dilanjutkan ke tahap berikutnya yaitu siklus II.

Pada siklus II terjadi peningkatan ketuntasan belajar klasikal penilaian pengetahuan sebesar $25 \%$ dan penilaian keterampilan sebesar 50\%. Berdasarkan perolehan persentase ketuntasan belajar klasikal penilaian pengetahuan sebesar $75 \%$ dan penilaian keterampilan sebesar $100 \%$, maka disimpulkan bahwa ketuntasan belajar pada siklus II telah tercapai.

\section{PENUTUP}

\section{Simpulan}

Simpulan pertama dari penelitian ini adalah implementasi pendekatan saintifik dengan media video narasi berhasil meningkatkan penguasaan materi pembelajaran daur air tema peristiwa dalam kehidupan pada peserta didik tunarungu. Implementasi tersebut diuraikan dalam perencanaan, pelaksanaan, dan evaluasi. Perencanaan pembelajaran materi daur air tema peristiwa dalam kehidupan, dengan pendekatan saintifik bercirikan langkah-langkah mengamati, menanya, mencoba, menalar, dan mengkomunikasikan. Penggunaan media video narasi terlihat dalam langkah mengamati, menanya, mencoba, dan menalar. Namun, langkah yang paling utama dalam menggunakan media video narasi adalah pada langkah mengamati. Pelaksanaan pembelajaran pada materi daur air tema peristima dalam kehidupan, dilakukan sesuai dengan langkah-langkah pendekatan saintifik dan video narasi sebagai medianya. Langkah mengamati memfokuskan peserta didik untuk membaca narasi (teks) pada video dan mengamati tayangan video. Langkah menanya memfokuskan peserta didik pada membiasakan peserta didik untuk menanyakan hal-hal yang belum dimengerti dari tayangan video dan menumbuhkan rasa ingin tahu. Langkah mencoba memfokuskan peserta didik untuk mencari tahu sendiri atau mencari informasi dari penayangan video. Langkah menalar memfokuskan peserta didik untuk mendiskusikan informasi yang diperoleh dari tayangan video. Langkah mengkomunikasikan memfokuskan peserta didik untuk menyampaikan hasil diskusi atau hasil pekerjaan peserta didik tunarungu dengan mempresentasikannya di hadapan teman-temannya. Pada pelaksanaannya, terdapat beberapa revisi yang dilakukan peneliti untuk memperbaiki kelemahan yang terdapat pada siklus I. Revisi tersebut antara lain penayangan video narasi diberi jeda agar peserta didik tunarungu mempunyai kesempatan untuk mengamati lebih seksama, memberikan penjelasan dan padanan kata untuk istilah ilmiah yang ada pada teks (narasi), mengarahkan peserta didik untuk saling bekerjasama saat diskusi kelompok. Evaluasi pembelajaran dilakukan dengan menilai kompetensi sikap spiritual, sikap sosial, pengetahuan dan keterampilan. Penilaian sikap spiritual dan sosial didapatkan dari pengamatan, penilaian pengetahuan diperoleh dari tes, dan penilaian keterampilan diperoleh dari hasil penilaian unjuk kerja.

Simpulan selanjutnya adalah terjadi peningkatan penguasaan materi pembelajaran daur air pada tema peristiwa dalam kehidupan dari siklus I ke siklus II berdasarkan penilaian pengetahuan: 
mengalami peningkatan sebesar 25\% (Nilai klasikal penilaian pengetahuan siklus I $=50 \%$, siklus $\mathrm{II}=75 \%$ ) dan penilaian keterampilan mengalami peningkatan sebesar 50\% (N klasikal penilaian keterampilan siklus I $=50 \%$, siklus II $=100 \%$ ). Penelitian ini dikatakan berhasil jika $75 \%$ peserta didik mencapai $\mathrm{N} \geq 70$. Target keberhasilan untuk penilaian pengetahuan mencapai $75 \%$ dan untuk penilaian keterampilan 100\%.

\section{Saran}

Berdasarkan pembahasan penelitian dan simpulan penelitian, maka dapat disarankan hal sebagai berikut: (1) dalam melaksanakan pembelajaran untuk peserta didik tunarungu dengan media video narasi sebaiknya diberi jeda saat penayangan video agar peserta didik tunarungu mempunyai kesempatan untuk mengamati lebih seksama, diberikan penjelasan dan padanan kata untuk istilah ilmiah yang ada pada teks (narasi), diarahkan untuk saling bekerjasama saat diskusi kelompok; (2) guru yang memiliki masalah pembelajaran yang sama dapat menerapkan pendekatan saintifik dengan media video narasi untuk meningkatkan penguasaan materi pembelajaran bagi peserta didik. Di kelas peserta didik tunarungu, materi pembelajaran lebih disederhanakan, kegiatan seperti mengamati, menanya, mencoba, menalar, dan mengkomunikasikan, harus dibimbing dan didampingi dalam pelaksanaannya.

\section{DAFTAR RUJUKAN}

Akram, B., Mehboob, R., Ajaz, A., \& Bashir, R. (2013). Scientific Concept of Hearing and Deaf Students of Grade VIII. Journal of Elementary Education, vol. 23, no 1 pp 1-12.

Arsyad, A. (2011). Media Pembelajaran. Jakarta: PT Raja Grafindo Persada.

Biemiller, A. (2005). Vocabulary development and instruction: A prerequisite for school learning. In D.Dickinson \& S.Neuman (Eds.), Handbook of Early Literacy Research, Vol.2 . New York, NY: Guilford Press.

Cassettari, Lam C., Wadnerkar, M.B., Kamble, \& James, D.M. (2015). Enhanching Parent-Child Communication and Parental Self-Esteem with a Video-Feedback Intervention: Outcomes with Prelingual Deaf and Hard-of- Hearing Children. Journal of Deaf Studies and Deaf Education. March, 28, 2015. 266-274.

Cirtha, I. (2012). Peningkatan Hasil Belajar IPA Peserta didik Kelas VI Dengan Penerapan Pembelajaran Kontekstual Berbantuan Media CD Interaktif Dilengkapi Bahasa Isyarat di SLB-B Negeri Singaraja. E-journal pasca.undiksha.ac.id.

Dias, L. et al., (2014). Deafness and the Educational Rights; A Brief Review through a Brazilian Perspective. Scientific Research. Scientific Research Publishing Inc. Published Online April 2014.

Febriana, G., Yunus, M., \& Tarmansyah. (2014). Efektifitas Penggunaan Media Video untuk Meningkatkan Kemampuan Mengenal Bahaya HIV/AIDS bagi Remaja Tunarungu. E-JUPEKhu (Jurnal Ilmiah Pendidikan Khusus). Vol.3. no.2, April 2014. http://ejournal. unp.ac.id/index.php/jupekhu.

Jones, L. (2014). Developing Deaf Children's Conceptual Understanding and Scientific Argumentation Skills: A Literature Review. Deafness \& Education International. Vol.16 No.3, September, 2014, 146-160.

Kemendikbud. (2013). Permendikbud. 81a. Tentang Implementasi Kurikulum. Jakarta: Kementerian Pendidikan dan Kebudayaan.

Kemmis, S., \& Mc Taggart, R. (2000). 'Participatory Action Research', in N Denzin and Y. Lincoln. (eds.), Handbook of Qualitative Research. London: Sage. 
Keraf, G. (2010). Argumentasi dan Narasi. Jakarta: Gramedia.

Machin, A. (2014). Implementasi pendekatan Saintifik, penanaman Karakter dan Konservasi pada pembelajaran Materi Pertumbuhan. Jurnal Pendidikan IPA Indonesia. http://journal. unnes.ac.id/nju/index.php/jpii.

Moores, D. (2001). Educating the Deaf: Psychology, Principles, and Practice. Boston: Houghton Mifflin Company.

Prahastiwi, R.B., Subani, \& Haryoto, D. (2012). Penerapan Pendekatan Saintifik Untuk Meningkatkan Karakter Rasa Ingin Tahu dan Prestasi Belajar Peserta didik Kelas X SMA Negeri 6 Malang. Jurusan Fisika FMIPA, Universitas Negeri Malang.

Rasyidi, M., Supartono, \& Yuniastuti, A. (2015). Development of Teaching Materials with Scientific Approach to Improve Students 'Critical Thinking Skill. Semarang State University.

Somantri, S. (2006). Psikologi Anak Luar Biasa. Bandung: PT Refika Aditama.

Traxler, C.B. (2000). The Stanford Achievement Test, 9th edition: National norming and performance standarts for deaf and hard-of-hearing students. Journal of Deaf Studies and Education, 5(4), 337-348.

Wahyudi, A. \& Sujarwanto. (2015). Metodologi Penelitian Pendidikan (SSR \& PTK). Surabaya: Unesa Unipress.

Zamfirov, M., \& Saeva, Sv. (2012). School Activities in Natural Sciences for Students with Special Needs in Bulgaria. Journal of Science Education for Students with Disabilities. Vol.16, Issue I Winter 2012/2013. 